\title{
Pembinaan Dan Pengawasan Notaris Mantan Narapidana Oleh Majelis Pengawas Notaris Di Daerah Istimewa Yogyakarta
}

\author{
Satria Akbar Nagara \\ Magister Kenotariatan Fakultas Hukum Universitas Islam Indonesia Yogyakarta Indonesia \\ Jln. Cik Di Tiro No. 1 Yogyakarta Indonesia \\ satria.akbar75@gmail.com
}

Key Word:
Supervisory Board of
Notaries, Notaries,
Prisoners

Abstract

This article examines the Guidance and Supervision of Notary Former Convicts by the Notary Supervisory Council based on UUJN and Permenkumham. The problem that is formulated is how to develop and supervise ex-convict Notaries by the Notary Supervisory Council in DIY, and what are the obstacles to fostering and supervising ex-convict Notaries by the Notary Supervisory Council in DIY. This type of research is normative which is supported by information from resource persons with a statutory approach and a conceptual approach. Legal materials were analyzed descriptively qualitatively. The results of this study conclude that the Guidance and Supervision carried out by the Notary Supervisory Council is guided by the UUJN and the RI Regulation of the Minister of Law and Human Rights No. 15 of 2020 while the Guidance and Supervision carried out by the Notary Supervisory Council to former Notary Convict members is an annual examination that has been regulated in the Notary Position Law. In the Picking Test of the Notary protocol, there has been no special attention or agenda in the regular monitoring of Notary Ex-Convicts and the obstacles that occur in the guidance and supervision, due to the Notary Supervisory Council which does not yet have special rules in carrying out its duties, thus triggering several subjective factors in viewing and assess the effectiveness of the guidance and supervision of the Notaries involved

Kata-kata Kunci:
Majelis Pengawas
Notaris, Notaris,
Narapidana

\section{Abstrak}

Artikel ini meneliti tentang Pembinaan dan Pengawasan Notaris Mantan Narapidana Oleh Majelis Pengawas Notaris berdasarkan UUJN dan Permenkumham. Masalah yang dirumuskan adalah bagaimana Pembinaan dan Pengawasan terhadap Notaris mantan narapidana oleh Majelis Pengawas Notaris di DIY, dan apa yang menjadi kendala pembinaan dan pengawasan notaris mantan narapidana oleh Majelis Pengawas Notaris di DIY. Jenis penelitian ini adalah Normatif yang didukung dari keterangan Narasumber dengan pendekatan perundang-undangan dan pendekatan konseptual. Bahan hukum dianalisis secara deskriptif kualitatif. Hasil penelitian tersebut menyimpulkan bahwa Pembinaan dan Pengawasan yang dilakukan Majelis Pengawas Notaris berpedoman UUJN dan Permenkumham RI No.15 Tahun 2020 sedangkan Pembinaan dan Pengawasan yang dilakukan oleh Majelis Pengawas Notaris kepada anggota Notaris Mantan Narapidana adalah pemeriksaan tahunan yang sudah diatur dalam Undang Undang Jabatan Notaris. Dalam Uji Petik protokol Notaris belum ada perhatian atau agenda khusus dalam monitoring secara berkala terhadap Notaris Mantan Narapidana dan Kendala yang terjadi dalam pembinaan dan pengawasan, disebabkan oleh Majelis Pengawas Notaris yang belum memiliki aturan khusus dalam menjalankan tugasnya sehingga memicu beberapa faktor yang bersifat subyektif dalam melihat dan menilai keefektifan pembinaan dan pengawasan terhadap Notaris yang terlibat 


\section{Pendahuluan}

Adanya kepastian, ketertiban dan perlindungan hukum dalam lalu lintas hukum pada umumnya memerlukan alat bukti yang menentukan dengan jelas hak dan kewajiban seseorang sebagai sebagai subjek hukum dalam masyarakat. Dalam kaitannya dengan kepastian hak dan kewajiban hukum seseorang dalam kehidupan masyarakat, salah satu dilakukan dengan adanya peran oleh Notaris. Pentingnya peranan Notaris dalam membantu menciptakan kepastian dan perlindungan hukum bagi masyarakat lebih bersifat pencegahan terjadinya masalah hukum, dengan cara penerbitan akta otentik yang dibuat dihadapannya terkait dengan status hukum, hak dan kewajiban seseorang dalam hukum dan lain sebagainya, yang berfungsi sebagai alat bukti yang sempurna. ${ }^{1}$

Apabila Notaris melanggar kewajiban, larangan serta ketentuan yang di atur di dalam Undang-Undang Republik Indonesia Nomor 2 Tahun 2014 tentang Perubahan Atas Undang-undang Nomor 30 Tahun 2004 tentang Jabatan Notaris maka akan dikenakan sanksi administratif antara lain peringatan tertulis, pemberhentian sementara, pemberhentian dengan hormat, dan perberhentian tidak hormat. ${ }^{2}$

Dalam tataran aturan hukum yang benar bahwa Majelis Pengawas Daerah harus menempatkan akta Notaris sebagai objek karena notaris dalam menjalankan tugas jabatannya berkaitan untuk membuat dokumen hukum berupa akta sebagai alat bukti tertulis yang berada dalam ruang lingkup hukum perdata sehingga menempatkan akta sebagai objek harus dinilai berdasarkan aturan hukum yang berkaitan dengan pembuatan akta. ${ }^{3}$

Peranan dan kewenangan Notaris sangat penting dalam kehidupan masyarakat, maka setiap perilaku dan perbuatan yang dilakukan Notaris dalam menjalankan tugasnya sangatlah rentan terhadap penyalahgunaan jabatan profesinya sehingga dapat merugikan masyarakat, oleh karena itu diperlukan suatu badan yang melakukan pengawasan dan pembinaan terhadap notaris. Tujuan pengawasan dilakukan terhadap notaris adalah untuk memenuhi persyaratan-persyaratan dan menjalankan tugasnya sesuai dengan ketentuanketentuan perundang-undangan berlaku untuk keamanan kepentingan masyarakat umum. Menteri Hukum dan Hak Asasi Manusia (HAM) melaksanakan tugasnya membentuk Majelis Pengawas. Majelis Pengawas yang dibentuk oleh Menteri Hukum dan Hak Asasi Manusia (HAM) ini terdiri dari unsur pemerintah, organisasi notaris dan ahli atau akademisi. Majelis Pengawas yang dimaksud adalah Majelis Pengawas Daerah, Majelis Pengawas Wilayah dan Majelis Pengawas Pusat. Dalam pelaksanaan pengawasan Notaris ditiap daerah kabupaten/kota terdapat Majelis Pengawas Daerah Notaris. ${ }^{4}$

Hal yang sama juga diatur dalam pasal lanjutan Pasal 13 Undang-Undang Jabatan Notaris, adapun bunyi pasalnya "Notaris diberhentikan dengan tidak hormat oleh

\footnotetext{
${ }^{1}$ Sjaifurrachman, Habib adjie, Aspek Pertanggungjawaban Notaris Dalam Pembuatan Akta, Cetakan I, Mandar Maju, Bandung, 2011, hlm. 7

2 Undang-Undang Nomor 2 Tahun 2014 Perubahan atas Undang-Undang Nomor 30 Tahun 2004 tentang Jabatan Notaris

3 Adjie Habib, Merajut Pemikiran dalam Dunia Notaris dan PPAT, cetakan ke-2, Citra Aditya Bakti, Bandung, 2014, hlm. 37-38

4 Adjie Habib, Hukum Notaris Indonesia Tafsir Tematik Terbadap Undang-Undang Nomor 30 Tabun 2004 tentang Jabatan Notaris, Refika Aditam , Surabaya, 2007, hlm. 173
} 
Menteri karena dijatuhi pidana penjara berdasarkan putusan pengadilan yang telah memperoleh kekuatan hukum tetap karena melakukan tindak pidana yang diancam dengan pidana penjara 5 tahun atau lebih". 5

Dalam Pasal 12 Undang-undang Republik Indonesia Nomor 2 Tahun 2014 tentang Perubahan Atas Undang-Undang Nomor 30 Tahun 2004 tentang Jabatan Notaris menjelaskan bahwa, Notaris dapat diberhentikan oleh Menteri atas usul Majelis Pengawas.Peranan dan kewenangan Notaris sangat penting bagi lalu lintas hukum dalam kehidupan bermasyarakat, maka perilaku dan tindakan notaris dalam menjalankan fungsi kewenangan, rentan terhadap penyalahgunaan yang dapat menimbulkan kerugian bagi masyarakat, sehingga terhadap Permenkumham RI No. 15 Tahun 2020 tentang tata cara pemeriksaan Majelis Pengawas terhadap Notaris sudah sesusai penerapatan aturan yang dilaksanakan Majelis Pengawas Notaris di Daerah Istimewa Yogyakarta atau belum dalam praktik dilapangan.

Berdasarkan apa yang telah diuraikan yang telah penulis jabarkan, penulis ingin melakukan penelitian seputar pengawasan, pembinaan dan pengawasan merupakan hal penting yang harus dilakukan oleh Majelis Pengawas Notaris mengenai ukuran pemberhentian tidak hormat dalam Pasal 12 dan Pasal 13 Undang-Undang Jabatan Notaris. Serta Bagaimana peran Majelis Pengawas Notaris di Daerah Istimewa Yogyakarta dalam melakukan pembinanaan dan pengawasan terhadap Notaris yang sudah dipidana kurang dari 5 tahun dan melakukan praktek kembali dengan status Notaris tersebut pernah menjadi narapidana dengan putusan pengadilan yang mempunyai kekuatan hukum yang tetap.

\section{Rumusan Masalah}

Berdasarkan uraian permasalahan, penulis merumuskan permasalahan bagaimana pembinaan dan pengawasan terhadap Notaris mantan narapidana oleh Majelis Pengawas Notaris di DIY dan apa yang menjadi kendala pembinaan dan pengawasan notaris mantan narapidana bagi Majelis Pengawas Notaris di DIY.

\section{Tujuan Penelitian}

Penelitian ini bertujuan untuk mengetahui dan menganalisis pembinaan dan pengawasan Notaris mantan narapidana di DIY oleh Majelis Pengawas Notaris dan untuk mengetahui dan mengkaji hal yang menjadi kendala dalam pembinaan dan pengawasan notaris mantan narapidana oleh Majelis Pengawas Notaris di DIY.

\section{Metode Penelitian}

Metode penelitian yang digunakan adalah normatif dengan analisis data menggunakan deskriptif analitik, teknik pengumpulan data dilakukan melaui teknik studi dokumenter dan wawancara. Pendekatan penelitian menggunakan statute approach, dimana penulis menelaah semua undang-undang dan regulasi yang bersangkutan

\footnotetext{
${ }^{5}$ Undang-Undang Nomor 30 Tahun 2004 tentang Jabatan Notaris
} 
dengan isu hukum yang dibahas dan pendekatan konseptual melihat dari berbagai padangan dan doktrin yang berkembang dalam ilmu hukum dengan mencermati membahas dan mempelajari ilmu-ilmu hukum yang berkembang.

\section{Hasil Penelitian dan Pembahasan}

\section{Pelaksanaan Pembinaan dan Pengawasan terhadap Notaris mantan narapidana oleh Majelis Pengawas Notaris di DIY}

Undang-Undang Jabatan Notaris dalam beberapa pasalnya dan mengatur dengan jelas komposisi pengawan diatur dalam Pasal 67 ayat (3) UUJN tertulis bahwa Majelis Pengawas terdiri dari 9 orang yang terdiri dari unsur-unsur :

1. Pemerintah sebanyak 3 orang;

2. Organisasi Notaris sebanyak 3 oang;

3. Ahli/Akademik sebanyak 3 orang.

Pengawasan kepada notaris melalu majelis pengawas dapat menjadi efektif apabila ada pembagian wilayah dalam pengawasannya. Berdasarkan Pasal 68 Undang Undang Jabatan Notaris, Majelis Pengawas terdiri atas :

1. Majelis Pengawas Daerah;

2. Majelis Pengawas Wilayah;

3. Majelis Pengawas Pusat. 6

Segala kewenangan yang diatur dalam undang-undang yang dilakukan oleh Notaris juga mempunyai resiko tindak pidana karena melakukan pelanggaran terhadap tugas dan jabatannya yaitu melakukan perbuatan yang melanggar undang-undang yang mengatur atau berlaku, peristiwa pidana dalam hukum positif, adalah suatu peristiwa yang oleh undang-undang ditentukan sebagai suatu peristiwa yang menyebabkan dijatuhkan hukuman. Hal ini karena berpegang pada suatu asas hokum tidak dapat dijatuhkan hukuman, apabila tidak ada suatu perbuatan yang bertentangan dengan hukum dan yang diadakan karena kesalahan pembuatnya. Jadi, makna teori ini dapat dirumuskan menjadi setiap kesalahan yang dilakukan dan bertentangan hukum maka akan mendapat hukuman. ${ }^{7}$

Notaris yang di bina dan diawasi oleh MPN yaitu dilakukan satu tahun sekali berdasarkan UUJN dengan metode uji petik yang dilakukan oleh MPD dan Majelis Pengawas Wilayah dalam melakukan pembinaan dan pengawasan berdasarkan limpahan dari MPD berdasarkan laporan dan temuan temuan yang direkomendasikan MPD melalui berita acara pemeriksaan, yaitu berupa investigasi independen dengan melakukan pemanggilan, untuk mencari kebenaran atau hal-hal yang MPW belum tau atau meragukan hasil pemeriksaan oleh MPD di lapangan. Majelis Pengawas Notaris melakukan pengawasan dilakukan secara hirarkis dengan dibentuknya majelis pengawas oleh menteri dengan tahapan MPD, MPW, MPP, dan MPN akan sangat responsive jika terdapat laporan masyarakat yang dirugikan oleh Notaris yaitu melakukan pemeriksaan

${ }^{6}$ Dwikky Bagus Wibisono dan Umar Ma'ruf, "Peranan Majelis Pengawas Daerah (MPD) Terhadap Pengawasan Pelaksanaan Jabatan Notaris Di Kabupaten Tegal”, Jurnal Ilmiah Prodi Magister Kenotariatan, vol 5 nomor 1 Tahun 2018

${ }^{7}$ Andi Hamzah, Asas-Asas Hukum Pidana, Rineka Cipta, Jakarta, 1994. hlm. 89 
dan pengawasan secara insidensial, dalam melakukan pembinaan pemanggilan terus menerus kepada Notaris yang belum mengikuti koridor hukum, dalam pemeriksaan juga beriringan dengan pembinaan.

MPN sangat konsen dalam menertibkan para Notaris agar sesuai dengan UUJN dalam melakukan pekerjaanya, sehingga terdapat perhatian khusus kepada Notaris yang pernah menjadi mantan narapidana sehingga mendapat pemberhentian sementara dengan cara melakukan pemeriksaan dengan ketat dalam proses uji petik agar mendapatkan hasil pemeriksaan yang memuaskan. Pemberian nilai atas hasil pemeriksaan para Notaris membuat Notaris harus mempertahankan penilaian atau yang belum mendapat nilai yang baik segera memperbaiki diri, pastinya kepada Notaris yang pernah melakukan tindak pidana dan mendapat pemberhentian sementara mendapatkan catatan dan nilai kurang memuaskna dari MPN sehingga menjadi sanksi social dan membuat Notaris mantan narapidana harus memperbaiki diri.

Perbedaan pembinaan yang dilakukan oleh MKN dan MPN terletak pada objek yang di bina (Notaris), MKN melakukan pembinan terhadap Notaris yang dipanggil oleh penyidik, Penuntut Umum dan Hakim. MPN melakukan pembinaan secara berkala terhadap semua Notaris disaat melakukan pemeriksaan protokol Notaris sebagai pengawasan dan pembinaan yang meliputi pelaksanaan tugas Jabatan Notaris, Prilaku Notaris dan Kode Etik Notaris.

MPN juga bersinergi dengan organisasi atau perkumpulan Notaris yaitu INI dengan mengadakan diskusi atau seminar seminar kecil untuk terus membina para anggota Notaris, bahkan MPN juga bersinergi dengan kampus-kampus FH di Daerah Istimewa Yogyakarta untuk menciptatakan produk lulusan yang baik secara keilmuan dan praktek serta mempunyai pribadi yang tangguh, dispilin, jujur dan menjunjung tinggi maratabat Notaris.

\section{Kendala Pembinaan dan Pengawasan Notaris Mantan Narapidana oleh Majelis Pengawas Notaris di DIY}

Pembinaan dan pengawasan yang dilakukan berkala juga tidak dapat sepenuhnya efektif untuk membuat Notaris tersebut tidak melakukan perbuatannya lagi dikarenakan adanya kesempatan, dan juga persaingan yang membuat Notaris menjadi gelap mata dalam melakukan tugas jabatannya. Berdasarkan pada nilai, moral, dan etik Notaris, maka hakekat pengembanan profesi jabatan Notaris adalah pelayanan kepada masyarakat (klien) secara mandiri dan tidak memihak. Sebagai pejabat umum, Notaris harus memiliki etika kepribadian Notaris, yaitu:

1. Berjiwa Pancasila;

2. Taat kepada hukum, sumpah jabatan Notaris, kode etik Notaris;

3. Notaris menertibkan diri sesuai dengan fungsi, kewenangan, dan kewajiban sebagaimana ditentukan dalam Peraturan Jabatan Notaris;

4. Berbahasa Indonesia yang baik.

Pembinaan dan pengawasan Notaris yaitu hasil kinerja MPN bisa dinilai secara subyektif dikarenakan efektifnya suatu pengawasan dilihat dari anggota Notaris sendiri apakah tiap individu Notaris yang pernah menjadi mantan narapidana mengulangi perbuatannya lagi, jika dilihat secara keseluruhan Majelis Pengawas Notaris dikatakan 
efektif dikarenakan bisa menekan angka anggota Notaris yang melakukan kembali kesalahannya dan meminimalisir Notaris yang lain untuk tidak terpeleset kedalam permasalahan yang dapat menimbulkan perbuatan pidana.

Beberapa contoh kendala MPN dalam melakukan pembinaan dan pengawasan yang terjadi dilapangan adalah Dalam prakteknya sidang MPW tidak boleh diwakilkan sehingga membuat pemeriksaan terhambat, Notaris sering melakukan pembelaan diri ketika diperiksa oleh MPW dengan memberikan argumen dan alasan yang kuat untuk melakukan sanggahan atas hasil pemeriksaan MPD, maka dari itu MPW perlu melakukan pembinan dan pengawasan yang lebih teliti dan cermat dalam melakukan pemeriksaan kepada Notaris yang sering kali melakukan pelanggaran atau Notaris yang pernah melakukan tindak pidana.

Data yang MPW cari atau data serta pengakuan yang diinginkan tidak tercapai karena ada oknum Notaris yang dengan sengaja menyembunyikan fakta-fakta yang terjadi, kendala ini sering terjadi disetiap instansi atau bahkan organisasi yaitu adanya kedekatan emosional baik karena rekan sejawat ataupun adanya hubungan keluarga tetapi dalam hal ini dengan integritas tinggi MPW dapat mengesampingkan dan bekerja secara professional dalam melakukan pembinaan dan pengawasan kepada anggota Notaris, kendala ini tidak begitu membebani dikarenakan konsistensi dan orang-orang pilihan untuk menjunjung tinggi kebenaran serta kedisiplinan kepada profesi jabatan Notaris yang ditunjuk menjadi anggota MPW untuk menjaga martabat dan marwah Notaris sebagai profesi yang mulia serta menjaga nama baik profesi jabatan Notaris. Kendala di lapangan beberapa oknum Notaris tidak memelihara protokol Notaris dengan baik sehingga dalam uji petik yang dilakukan oleh MPD tidak maksimal, sedangkan dalam Undang-Undang No. 2 Tahun 2014 Pasal 1 ayat (13) berbunyi protokol Notaris adalah kumpulan dokumen yang merupakan arsip negara yang harus disimpan dan dipelihara oleh Notaris sesuai dengan ketentuan peraturan perundang-undangan.

Metode yang dilakukan oleh MPN dalam melakukan pemanggilan berkali kali terhadap Notaris yang bermasalah ataupun Notaris yang sudah menjadi mantan narapidana menurut penulis masih kurang efektif dikarenakan jika terus menerus ada pemanggilan dapat ditarik kesimpulan terjadinya pemanggilan terus menerus kepada anggota Notaris yang mempunyai catatan buruk karena kesalahannya dapat melakukan pengulangan, dikarenakan sifat Notaris iytu berbeda tiap individu sehingga ada beberapa Notaris yang memang tidak bisa di bina dengan cara-cara yang persuasif.

Tidak ada tindakan sanksi yang tegas dikarenakan terbentur aturan UUJN yang mengatur bahwa tindakan tegas berupa sanksi pemberhentian tidak hormat oleh menteri dapat dilakukan jika Notaris tersebut mendapatkan ancaman pidana 5 tahun, menurut penulis belum efektif sehingga efek jera kepada Notaris yang melakukan kesalahannya suatu saat akan mengulangi perbuatanya diperlukan aturan dan juga suatu badan yang mengawasi khusus terhadap Notaris mantan narapidana karena jabatannya serta lebih meningkatkan pembinaan dan pengawasan kepada Notaris di Daerah Istimewa Yogyakarta dengan cara membuat mekanisme laporan berkala kepada Majelis Pengawas Notaris dan hanya dikelola satu instansi saja dengan rentan waktu yang dekat untuk memonitoring Notaris mantan narapidana sehingga diharapkan dapat meminimalisir adanya pelanggaran Notaris di Daerah Istimewa Yogyakarta. 


\section{Penutup}

Pembinaan dan pengawasan yang dilakukan oleh Majelis Pengawas Notaris terhadap notaris mantan narapidana di DIY sama seperti pembinaan notaris pada umumnya sesuai dengan UUJN No. 2 Tahun 2014 dan Permenkumham No. 15 Tahun 2020, meliputi pelaksanaan secara langsung maupun tidak langsung, berupa uji petik protokol notaris dengan memeriksa tugas Jabatan Notaris, Prilaku Notaris dan Kode Etik Notaris yang dilaksanakan 1 tahun sekali secara teliti, cermat, dan efisien; Melakukan investigasi independen; Melakukan gelar perkara pemanggilan sidang sesuai prosedur; Pemberian teguran secara moral atau pendekatan persuasif sebagai kegiatan pembinaan oleh MPN yang bersinergi dengan Organisasi INI yang dilakukan secara berkala; dan Melakukan edukasi terhadap Notaris mantan narapidana sebagai pembinaan yang dilakukan bersamaan dengan uji petik oleh MPN. Sehingga dapat dikatakan MPN sudah melakukan pembinaan dan pengawasan yang sesuai dengan prosedur dalam UndangUndang Jabatan Notaris 2014.

Kendala dalam pembinaan dan pengawasan notaris mantan narapidana di DIY oleh Majelis Pengawas Notaris adalah ketidak seimbangan jumlah anggota Majelis Pengawas Notaris dengan jumlah anggota Notaris yang diawasi; Banyaknya laporan dari masyarakat yang dirugikan terhadap anggota Notaris sehingga MPN harus menganalisis dan memilah apakah kesalahan yang dilakukan Notaris tersebut masuk dalam wewenang Majelis Pengawas Notaris; Ketidak hadiran Notaris yang akan diperiksa atau mangkir dari pemanggilan pemeriksaan sehingga membuat pemeriksaan terhambat karena dalam prakteknya sidang MPW tidak boleh diwakilkan; Notaris sering melakukan pembelaan diri ketika diperiksa oleh MPN dengan memberikan argumen dan alasan yang kuat untuk melakukan sanggahan atas hasil pemeriksaan MPD; Data yang MPN cari atau pengakuan yang diinginkan tidak tercapai karena terdapat Oknum Notaris yang dengan sengaja menyembunyikan fakta-fakta yang terjadi; Adanya kedekatan emosional baik karena rekan sejawat ataupun adanya hubungan keluarga; Kendala dilapangan beberapa oknum Notaris tidak memelihara protokol Notaris dengan baik sehingga dalam uji petik yang dilakukan oleh MPD tidak maksimal; Secara aturan, uji petik dilakukan 1 tahun sekali, seharusnya untuk notaris mantan narapidana dapat dilakukan pengawasan secara khusus dan berkala untuk meminimalisir kemungkinan keterulangan kesalahan yang pernah dilakukan oleh notaris mantan narapidana tersebut; Kendala lainnya yaitu tidak dapat melakukan pemeriksaan secara bersamaan dalam satu waktu karena tidak mudah mendapatkan waktu yang sama.

\section{Daftar Pustaka}

\section{Buku}

Adjie, Habib, Hukum Notaris Indonesia Tafsir Tematik Terhadap Undang-Undang Nomor 30 Tahun 2004 tentang Jabatan Notaris, Refika Aditam , Surabaya, 2007.

Hamzah, Andi, Asas-Asas Hukum Pidana, Rineka Cipta, Jakarta, 1994.

Sjaifurrachman, Habib adjie, Aspek Pertanggungjawaban Notaris Dalam Pembuatan Akta, Cetakan I, Mandar Maju, Bandung, 2011. 


\section{Jurnal}

Wibisono, Dwikky Bagus dan Umar Ma'ruf, "Peranan Majelis Pengawas Daerah (MPD) Terhadap Pengawasan Pelaksanaan Jabatan Notaris Di Kabupaten Tegal", Jurnal Ilmiah Prodi Magister Kenotariatan, Vol 5 nomor 1 Tahun 2018

\section{Peraturan Perundang-undangan}

Undang-Undang Nomor 2 Tahun 2014 Perubahan atas Undang-Undang Nomor 30 Tahun 2004 tentang Jabatan Notaris

Undang-Undang Nomor 30 Tahun 2004 tentang Jabatan Notaris 